Wzniostość $i$ makabra w literackich obrazach śmierci, red. Michał Kuran, Łódź 2014, „Analecta Literackie i Językowe", t. IV.

\title{
Obsesja Śmierci w twórczości Augusta Antoniego JaKubowskiego i HeINRICHA Von KLEISTA
}

Jarosław Marek Rymkiewicz w eseju Dlaczego romantycy umierali młodo podkreślał, że poeci tamtej epoki ze szczególnym upodobaniem przebywali nie tyle na terytorium śmierci, co na jej pograniczu². W niniejszej pracy pragnę przedstawić losy dwóch artystów romantycznych: Augusta Antoniego Jakubowskiego i Heinricha von Kleista. Obaj poeci odważyli się przekroczyć tę granicę w rzeczywistości i targnęli się na własne życie. Analizując ich twórczość i biografie, ukażę skrajnie różne motywy, które popchnęły ich do ostateczności, a także zupełnie odmienne postrzeganie śmierci. Kleist pragnął jej, tak jak chorzy uzdrowienia. Zgon był dla niego początkiem wielkiej przygody, w jakiej miała mu towarzyszyć ukochana Henrietta. Parę połączyła paradoksalnie decyzja wspólnej śmierci, a nie życia. W przypadku niemieckiego poety zrekonstruuję również przygotowania do samobójstwa i jego wykonanie na podstawie listów pisarza, a także zeznań świadków. Postaram się też przybliżyć mało znaną postać nieślubnego syna Antoniego Malczewskiego - Augusta Antoniego Jakubowskiego. Młody poeta zabił się w wieku 21 lat, będąc na zesłaniu w Ameryce. Omówię jego w wielu aspektach autobiograficzną i pełną rozpaczy twórczość, w której uwypukla się dojrzewanie do śmierci jako jedynego wyzwolenia z obcego świata bez nadziei na powrót do ojczyzny.

Życie Jakubowskiego, syna autora Marii, wpisuje się w porządek klęski rodziny Malczewskich, w której prawie wszystkich spotkał tragiczny los. Zazwyczaj członkowie tego rodu umierali w niesławie, nędzy i opuszczeniu. Julian Maślanka, który odnalazł poezje młodzieńca w 1971 roku w Bibliotece Polskiej w Paryżu, nazwał Augusta Antoniego „poetą rozpaczy”, gdyż jego 21-letnie życie było prawdziwym pasmem cierpień. Jako patriota, będąc za młody do walki w powstaniu listopadowym, najprawdopodobniej wziął udział w pierwszej fazie partyzantki Zaliwskiego. Szybko został aresztowany, odcięty od ukochanej matki i przyjaciół, a następnie zesłany do Stanów Zjednoczonych, skąd nigdy już nie powrócił.

\footnotetext{
${ }^{1}$ Ewa Modzelewska — jest studentką V roku polonistyki i prawa Uniwersytetu Jagiellońskiego. Przez dwa lata pracowała jako dziennikarz „Gazety Krakowskiej”. Interesuje się nieznanymi, a także zapomnianymi twórcami epoki romantyzmu — jako pracę magisterską przygotowuje pierwszą monografię twórczości Augusta Antoniego Jakubowskiego.

${ }^{2}$ J. M. Rymkiewicz, Gtowa owinięta koszula, Warszawa 2012, s. 16.
} 
Pesymizm stał się głównym wyznacznikiem większości jego utworów i występuje on w takim natężeniu, jakie rzadko można spotkać u naszych poetów romantycznych. Obok swojego ojca Antoniego Malczewskiego oraz Seweryna Goszczyńskiego wpisuje się Jakubowski w nurt czarnego romantyzmu, a także jawi się jako prekursor tak zwanej „liryki ciemnej”, która na dobre rozwinęła się dopiero w Młodej Polsce. Jarosław Ławski podkreślił, że „poezje Jakubowskiego są [...] jeszcze bardziej przesycone pesymizmem niż poemat jego ojca. Przewija się w nich obsesyjnie motyw śmierci”3. Faktycznie, w niewielkim objętościowo tomiku, liczącym zaledwie 42 wiersze aż w $86 \%$ tych utworów powraca motyw umierania w najróżniejszych odsłonach albo sama sugestia śmierci. Jest ona obecna nawet w najwcześniejszych próbach poetyckich, pełnych epigońskiego wpływu popularnych wówczas autorów, zwłaszcza Mickiewicza. W dojrzalszych utworach często powraca postać martwego duchowo człowieka-upiora, wypalonego uczuciowo i wyalienowanego ze społeczeństwa, który tylko ciałem należy do ludzkiej wspólnoty ${ }^{4}$.

Jakubowski dużo miejsca poświęcał nieodwracalnej przemianie z pełnego marzeń poety, chcącego śpiewać „pieśń nieśmiertelności” w starego duchem tułacza, który nie widzi sensu życia i pragnie śmierci. Liryczne ,ja” jego wierszy przypomina bohaterów Godziny myśli, gdzie dziecko romantyczne w przeczuciu przyszłości jest smutne i nieszczęśliwe, a swoją młodość postrzega jako stanie „nad przepaści życia brzegiem”. Wydawać by się mogło, że Jakubowski jako poeta powinien przezwyciężý „zamkniętą egzystencję”, tak jak „dziecko o czarnych oczach”. Paradoksalnie jednak podzielił los starszego chłopca, który zginął śmiercią samobójcza, gdyż nigdy nie potrafił urzeczywistnić swoich marzeń.

Zaraz po aresztowaniu młody powstaniec tworzył buntownicze sonety, przesycone pragnieniem zemsty na zaborcach po stłumieniu rewolucji. Tonacja utworów radykalnie się zmieniła, kiedy przetransportowano go do więzienia w Brnie na Morawach. W napisanym miesiąc później liryku Pożegnanie. Improwizacja dominuje już nie tylko brak nadziei na pomszczenie ojczyzny, ale na odzyskanie niepodległości i jakiegokolwiek osobistego szczęścia. Pojawia się metafora lotu „ptaka w okowach”, a także przeczucie wiecznej rozłąki z najbliższymi i definitywne zamknięcie etapu radosnych nadziei. Syn Malczewskiego, czekając trzy miesiące na rozstrzygnięcie swego losu, był pełen najgorszych obaw i przeczuć. W coraz posępniejszym tonie tworzył kolejne utwory, takie jak Dumka Podolanina i Dzwon wieczorny. W pierwszym z nich autor nazywał siebie wygnańcem i zaznaczał „umarłych marzeń ślad”. Powraca motyw poże-

\footnotetext{
${ }^{3}$ J. Ławski, Malczewski - iluminacje i klęski melancholijnego wędrowca, [w:] A. Malczewski, Maria, powieść ukrainska, Białystok 2002, s. 116.

${ }^{4}$ Upiór stanowi tutaj postać reliktowego dualizmu Słowian. Nie ma dla niego miejsca w świecie żywych ani umarłych — podobnie jak dla bohatera wierszy Jakubowskiego. Ciało, tak jak w gnostyckich teoriach, jawi się jako więzienie duszy — zob. Z. Kaźmierczyk, Stowiańska psychomachia Mickiewicza, Gdańsk 2012, s. 173-175.

5 J. Słowacki, Powieści poetyckie, oprac. M. Kridl, Kraków 1949, s. 223.

${ }^{6}$ Tamże, s. 224.
} 
gnania, a także uwidacznia się pewność śmierci. Poeta zadręczał się także przeczuciem, że dzwon wieczorny słyszany w celi być może bije na zgon matki albo ukochanej.

Nastrój skrajnego pesymizmu wypełnia jego poezje pisane na fregacie Hebe, którą przez 128 dni płynął do Nowego Jorku. Stanowią one przejmujące świadectwo stanu ducha poety coraz bardziej oddalającego się od domu. We wcześniejszych utworach Jakubowski wyznawał, że w trudnych chwilach ukojenie przynosiły mu radosne wspomnienia przeszłości, nadzieja oraz ucieczka w krainę wyobraźni. Z biegiem czasu obudziło się w nim przeczucie, że już nigdy nie powróci do ojczyzny. Wskazując horyzont, stwierdzał: „Tam me życie, tam mój grób” łodzią Charona. Obsesyjnie w kolejnych lirykach jak refren powraca woda jako symbol śmierci. W Pożegnaniu Jakubowski pisał:

Grób mój będzie wielki jak ocean cały

Wielkość i nicość — czysty obraz zgonu ${ }^{8}$.

Natomiast w Dumaniu I zaznaczał: „To morze będzie moim grobem i siedliskiem”. Również w utworze Nad Morzem poeta ukazuje falę czarną jak wieko trumny. Gaston Bachelard podkreślał w Psychoanalizie obrazów wody, że każda stojąca, zamarła woda jest materią śmierci i zaproszeniem do niej. Dlatego jawi się ona nie tylko jako grób ognia, ale i ludzi, a także emblemat absolutnego snu zmarłych. Potencjalny zgon nie budził jednak strachu w Jakubowskim, lecz przynosił ulgę i nadzieję na uwolnienie od cierpień życia. Dominujący nastrój w utworach wygnańca to rezygnacja, a także oczekiwanie na nieuchronną katastrofę. Kiedy w wierszu Piramidy rozpaczał, że nie może tak jak one obojętnie patrzeć na zagładę swojego narodu, w Pożegnaniu, będąc już na statku, pisał, że jego łono jest „zimne jako łono fali” ${ }^{10}$. Liryk ten ma też znaczenie symboliczne i staje się jak gdyby pożegnaniem z życiem. Dwa wersy:

Jednak nade mną niech się nikt nie żali

Niechaj nade mną nikt nie ubolewa ${ }^{11}$.

przypominają słowa znanego utworu Wyspiańskiego: „Niech nikt nad grobem mi nie płacze", napisanego siedemdziesiąt lat później.

Wygnaniec zostaje naznaczony piętnem cierpienia, którego nic nie jest w stanie wymazać. Nawiedzające go wspomnienia nie są balsamem na ból istnienia, ale stale rozdrapują niezagojoną ranę. W poezjach Jakubowskiego mamy do czynienia z ciągłą konfrontacją radosnej przeszłości z ponurą teraźniejszością, gdzie nawet oddycha się śmiercią. Tak dzieje się między innymi w liryku Przemiana. Młodzieniec zestawia w nim czas, kiedy splatał wieniec z kwiatów z chwilą obecną:

\footnotetext{
${ }^{7}$ A. A. Jakubowski, Poezje, oprac. J. Maślanka, Kraków 1973, s. 38.

${ }^{8}$ Tamże, s. 41.

${ }^{9}$ Tamże.

${ }^{10}$ Tamże, s. 40.

${ }^{11}$ Tamże.
} 
Dzisiaj wędrowny młodzieniec

U cmentarza, u mogity

Zbieram kości na ten wieniec,

By jak naga myśl świeciły

Z czaszek ułożę ołtarze

Trawiący ogień rozniecę

I już więcej nie pomarzę

I już więcej nie polecę ${ }^{12}$

Jego pełne rozpaczy wiersze stanowią niezbity dowód pogłębiającej się depresji. Pokazują one zamknięcie się na świat, utratę wszelkiej nadziei, a w końcu dojrzewanie do śmierci i jej pragnienie. Nie jest to jednak owo pożądanie, Lust im Tode, które zaprowadziło Heinricha von Kleista nad jezioro Wansee. Jakubowski nie chciał żyć w świecie, który go „zdradził” i pogrzebał jego pragnienia. W utworach poety cały czas zaznacza się dysonans pomiędzy światem wewnętrznym bohatera a zewnętrzną rzeczywistością. Alfred Alvarez w książce Bóg Bestia. Studium samobójstwa podkreślał, że samobójcza depresja to coś na kształt duchowej zimy, która nasila się, gdy kontrastuje z pełnym życia światem zewnętrznym ${ }^{13}$. Powoli gasły w Jakubowskim wszystkie uczucia - nawet chęć zemsty i buntu. Poeta czuł się martwy już za życia. Dlatego też tak często w jego twórczości pojawia się „zwiędłe” serce przyrównywane do mogiły, urny z popiołami albo kry lodu czy wygasłego wulkanu. Trzeba zaznaczyć, że w swoich lirykach Jakubowski wpisuje się w estetykę symbolizmu związaną z tradycją Marii Malczewskiego. Wypływa ona z koncepcji wyalienowanej jaźni, która nie może wyjść poza samą siebie. Stąd w wierszach poety promienie świata zewnętrznego nie są w stanie przeniknąć do grobowca, a podmiot liryczny pogrążony jest w mroku i rozpaczy.

Pisarz nie odczuwał ekstazy śmierci tak jak Kleist. Swój przejmujący wiersz $D u-$ manie IV zamknął słowami: „Smutno po zgonie, nie smutniej niż w życiu”" ${ }^{14}$. Julian Maślanka stawia utwór ten obok Matki Polki Mickiewicza pomiędzy najbardziej wstrząsającymi i poruszającymi wierszami polskiego romantyzmu. W jego ponurej, pesymistyczno-melancholijnej tonacji pojawia się nachodząca zapewne poetę, prześladowcza myśl o rychłym i nieuniknionym samobójstwie. Odnosi się wrażenie, że Jakubowski liryk ten tworzył w stanie najgłębszej depresji i załamania nerwowego, tuż przed odebraniem sobie życia wystrzałem z pistoletu. Tragizm wiersza potęguje wyczuwalna autentyczność i prawdziwość sytuacji. Utwór ten w największym natężeniu kumuluje dotychczasowe katastroficzne tendencje i obsesyjne motywy śmierci w twórczości Jakubowskiego. Pogrążony w nieprzeniknionych ciemnościach, z zimnym sercem, które jawi się jako „kamień cmentarny z szczątkami szczęścia” ${ }^{15}$, poeta jest przekonany o bezsensie ludzkiego istnienia. Nie chce dłużej żyć w świecie, któ-

\footnotetext{
${ }^{12}$ Tamże, s. 57.

${ }^{13}$ A. Alvarez, Bóg Bestia: studium samobójstwa, przekł. Ł. Sommer, Warszawa 1997, s. 78.

${ }^{14}$ A. A. Jakubowski, dz. cyt., s. 61.

${ }^{15}$ Tamże, s. 60.
} 
ry go oszukał i mamił fałszywymi obietnicami. Syn Malczewskiego znów powtarza, że pieśń nieśmiertelności nie jest możliwa. Rzeczywistość, podobnie jak dla Kleista, nie przedstawia dla niego żadnej wartości. Jakubowski odciął się nie tylko od świata, ale także od Boga. Chcąc pokonać wahanie przed śmiercią, wzywał szatana ${ }^{16}$. Trzeba jednak zaznaczyć, że we wcześniejszych utworach poety postać diabła pojawiała się tylko w związku z pragnieniem zemsty i „zgonu starego świata”. ${ }^{17}$. Tym razem poeta świadomie wybrał potępienie, choć przeczuwał, że za grobem jego dusza nie znajdzie ukojenia. Niczym w geście rozpaczy Kierkegaarda woła:

\section{I czegoż jeszcze oglądasz się, czekasz? \\ Czego żałujesz? Czym gromów odwlekasz? \\ Uderz, ach uderz w szczątek twej istoty! \\ Nucił ci radość świat, gdyś był w powiciu, \\ I świat cię zdradził, a teraz w skonanie \\ Szatańskim głosem śpiewaj mi szatanie! ${ }^{18}$}

Jakubowski popełnił samobójstwo w Northampton 24 kwietnia 1837 roku, chociaż zadziwiająco szybko odnalazł się w trudnej dla wielu Polaków rzeczywistości Stanów Zjednoczonych. W przeciągu zaledwie 10 miesięcy tak biegle przyswoił sobie język angielski, że napisał w nim jedną z pierwszych antologii polskiej poezji The $R e$ membrances of a Polish Exile. Jeszcze za życia poety była ona wznawiana czterokrotnie przez najlepszych wydawców. Wśród amerykańskiej Polonii książka ta stała się nieodzownym biletem wizytowym. Jednocześnie syn Malczewskiego został zatrudniony w najlepszej szkole dla dziewcząt w USA — Gothic Seminary jako nauczyciel francuskiego, gdzie cieszył się powszechnym uznaniem i sympatią. Nikt nie przypuszczał, że młodzieniec u progu dobrze zapowiadającej się kariery, zawsze pogodny i pocieszający innych, odbierze sobie życie.

Również niemiecki poeta Heinrich von Kleist w młodym wieku popełnił samobójstwo. Jego postawa wobec śmierci różni się jednak zasadniczo od motywacji Jakubowskiego przede wszystkim dlatego, że obaj twórcy należeli do odmiennych kręgów kulturowych, cechujących się inną mentalnością i religijnością. Dominujący w kulturze niemieckiej XIX wieku idealizm powodował, że bohaterowie dzieł Goethego, Kleista czy Novalisa nawet w samobójczym akcie tęsknili za doskonałym światem jedynego Boga. W Fauście Goethego Mefistofeles nie może się równać ze Stwórcą, a jego poczynania zawsze skazane są na niepowodzenie. W pewnym momencie wypowiada on słowa, iż jego największą tragedią jest to, że zła pragnąc, zawsze czyni dobro. Zupełnie inaczej jest ze

\footnotetext{
${ }^{16}$ Kwestią otwartą pozostaje obecność reliktowego dualizmu w twórczości Jakubowskiego. Model ten zakłada dychotomię dualną, binarną opozycję miedzy równymi sobie Bogiem i diabłem, czyniąc świat strukturą antagonistyczną. W tym ujęciu obszarem psychomachii staje się również dusza człowieka. Należałoby rozważyć, czy utwory Jakubowskiego w swoim universum zakładają oddziaływanie tego modelu, który dzieli świat na opozycyjne wartości - zob. Z. Kaźmierczyk, $d z$. cyt.

${ }^{17}$ A. A. Jakubowski, dz. cyt., s. 46.

${ }^{18}$ Z. Kaźmierczyk, dz. cyt.
} 
słowiańskim dualizmem reliktowym, gdzie zarówno Dobry, jak i Zły Bóg są godnymi siebie przeciwnikami. Wstręt do życia bohaterów Kleista i decyzja o samobójstwie nie wiąże się z przekonaniem, że świat należy do szatana. Jakubowski natomiast świadomie wybiera potępienie i oddaje się władzy diabła w akcie skrajnej rozpaczy.

Powody odebrania sobie życia przez Kleista najlepiej obrazują słowa wyryte na nagrobku poety, pochodzące z jego najwybitniejszego dramatu o księciu Homburgu: „Teraz, o nieśmiertelności, jesteś cała moja” ${ }^{19}$. W pełni ukazują one nie tylko obsesję śmierci autora, ale też jej namiętne pożądanie, wypełniające zarówno utwory poety, jak i jego życie. To właśnie ekstaza śmierci połączyła Kleista i Henriettę Vogel, z którą 21 listopada 1811 roku popełnił „spektakularne” samobójstwo nad jeziorem Wanesee koło Poczdamu. Śmierć ta szybko obrosła legendą i uczyniła pisarza sławniejszym niż jego dzieło.

Przez wiele lat imię Henryka Kleista było niemal wyklęte w jego ojczystym kraju. Podwójne samobójstwo wstrząsnęło opinią publiczną i wywołało prawdziwy skandal. Jak pisze Wanda Markowska: „Król, dwór, sfery rządzące, armia, wszyscy zgodnie rzucili na zmarłego pisarza anatemę, występując $\mathrm{w}$ „obronie zagrożonej religijności i obyczajności ludu" ${ }^{20}$. Nie tylko śmierć Kleista, ale całe jego życie było szokującą perwersją w oczach współczesnego mu świata. Autor Pentesilei wielokrotnie rozpaczał, że nikt go nie rozumiał, nawet najbliżsi krewni. To właśnie jego szlachecka, ale zubożała rodzina zmusiła go do podjęcia opłacalnej kariery wojskowej, której szczerze nienawidził. Porzucił ją po siedmiu latach pomimo jawnej niechęci króla, ponieważ postanowił zostać poetą. Niestety, „każdy rodzaj pisarstwa” ${ }^{21}$ był uznany w jego sferze za hańbę, zajęcie najbardziej kompromitujące arystokratę. Mimo to Kleist podjął rozpaczliwą walkę o prawo tworzenia i realizację własnej indywidualności artystycznej marząc, że swym dziełem przyćmi Goethego. Przed samą śmiercią miał stwierdzić, że przyszło mu „doznać na świecie największych mąk, jakie przeżywał kiedykolwiek człowiek”. Literatura była nie tylko misją Kleista, ale stała się też jego przekleństwem — zamiast należnego uznania, spotykał się bowiem częściej z pogardą i obojętnością odbiorców. On sam zwierzał się przyjacielowi: „Gdybym umiał robić coś innego, całym sercem, $\mathrm{z}$ ochotą bym się tego uchwycił, tworzę wiersze tylko dlatego, że nie mogę się od nich uwolnić"22. Ten młody wojskowy o wyglądzie pucułowatego chłopca nie był wcale opanowany ani zdyscyplinowany. Cechowała go duża labilność nastrojów, chorobliwa ambicja i nadwrażliwość. Łatwo było go zranić i wyprowadzić z równowagi, dlatego tak często wyzywał na pojedynki swoich znajomych, wśród nich również Goethego, który dobiegał już sześćdziesiątki. Życie poety stanowiło pasmo niepowodzeń, wielkich marzeń i zawiedzionych nadziei. Jakiejkolwiek działalności się chwytał (wydawniczej, dziennikarskiej czy politycznej), prędzej czy później spotykało go dotkliwe

\footnotetext{
${ }^{19}$ H. Kleist, Dramaty wybrane, przekł. J. S. Buras, Kraków 2000, s. 337.

${ }^{20}$ Tenże, Listy, przekł. i wstęp W. Markowska, Warszawa 1983, s. 5.

${ }^{21}$ Tamże, s. 20.

${ }^{22}$ Tamże, s. 422.
} 
rozczarowanie. Porażki życiowe wpływały na jego stan psychiczny, który dziś moglibyśmy określić jako psychozę maniakalno-depresyjną. Po okresach euforii i radosnej aktywności twórczej nawiedzały go momenty załamania nerwowego oraz zwątpienia w sens swojego pisarstwa. W czasie depresji zniszczył jedno ze swych największych dzieł, wtedy również towarzyszyły mu myśli o umieraniu.

Kleist bardzo wcześnie zetknął się ze śmiercią: szybko został osierocony przez rodziców, a w wieku 14 lat wziął udział w pierwszej wyprawie wojennej. Wojciech Natanson wspomina, że zaledwie rok później pisarz razem ze swym kuzynem Pannwitzem postanowił, że dobrowolnie pójdą na śmierćéc ${ }^{23}$. Następnie namawiał na wspólne samobójstwo przyjaciela Pfuela, jednak prawdziwego towarzysza w śmierci odnalazł dopiero w Henriettcie Vogel. Wcześniej, jeszcze jako narzeczony Wilhelminy von Zenge, zniechęcał ją do troski o życie wieczne tłumacząc, że człowiek nie powinien zajmować się sprawami, których nie może pojąć. W ten sposób przezwyciężył kryzys duchowy, w jaki wpędził go kontakt z filozofią Kanta. Wkrótce jednak obojętność wobec śmierci zamieniła się w jej pragnienie. Nie jest to jeszcze owo pożądanie, które doprowadziło go nad jezioro Wannsee, lecz reakcja w mniemaniu Kleista na beznadziejną sytuację bez wyjścia. Legły bowiem w gruzach jego plany osiedlenia się w Szwajcarii, skromny majątek szybko topniał, a wszystkie próby literackie, jakie podejmował, nie przynosily spodziewanego sukcesu. Powoli tracił więc nadzieję na wielką sławę, a poprzysiągł sobie, że tylko opromieniony jej blaskiem, powróci do ojczyzny. Wciąż targały nim wątpliwości co do własnego talentu, zadręczał się obawami: „Zapewne nigdy już nie powrócę do ojczyzny $[. .$.$] i stanę się najpewniej w ciągu jednego roku zupełnym bie-$ dakiem”24. Myśl, że nie ma wsparcia i zrozumienia najważniejszej kobiety w jego życiu, stała się nie do zniesienia. W ostatnim liście do Wilhelminy z 20 maja 1802 roku poprosił: „Kochana moja, nie pisz do mnie więcej. Nie mam żadnego innego pragnienia poza tym jednym: umrzeć wkrótce" 25 . Chęć tworzenia i zyskania sławy nie pozwoliły mu poddać się jeszcze przez niemal dziesięć lat. Pisanie dzieł na miarę swoich wygórowanych oczekiwań nie przychodziło mu łatwo. Niską samoocenę i rozgoryczenie potęgowały wyrzuty sumienia, że przynosi wstyd rodzinie i do niczego się nie nadaje. Wpędzony w kłopoty finansowe, pisał zrozpaczony do swego szwagra Pannwitza: „Boga proszę o śmierć, a Ciebie o pieniądze [...] Nie mogę Ci opisać, jak bardzo cierpię. Najchętniej uciekłbym tam, gdzie od wieków ludzka stopa nie postała”26.

Z kolei w liście do swojego mecenasa, barona Altensteina, wyrażał przekonanie, że człowiek nie może być szczęśliwy na świecie „gdzie wszystko kończy się śmiercią"27. A jednak pięć lat później to właśnie śmierć wyda mu się jedynym spełnieniem i obietnicą przyszłego szczęścia. Z biegiem czasu refleksje o umieraniu zajmują coraz więcej

\footnotetext{
${ }^{23}$ W. Natanson, Sprawa Henryka Kleista, „Twórczość” 1958, nr 12, s. 107.

${ }^{24}$ H. Kleist, Listy, s. 267.

${ }^{25}$ Tamże.

${ }^{26}$ Tamże, s. 396.

${ }^{27}$ Tamże, s. 418.
} 
miejsca w epistolarnej spuściźnie Kleista. Podkreślał on, że doświadczenie jednostkowej śmierci, będącej dla każdego końcem świata, na przestrzeni dziejów pozostaje niezmienne mimo ciągłej ewolucji człowieka. Stąd mówił o sobie, że umrze ,jedną z tych milionów śmierci, którymi już umieraliśmy i jeszcze nadal będziemy umierać"28. W kolejnych listach nasilają się pesymistyczne sądy o rzeczywistości, będącej dla poety synonimem cierpienia, od którego nie można uwolnić się nawet w myślach ${ }^{29}$. Od roku 1807 zaznacza się przełom w postrzeganiu śmierci przez pisarza. Obok pejoratywnych określeń świata, pojawia się krytyka życia jako męczarni, której wytchnienie daje tylko jego refren — śmierć. Pierwszy raz Kleist zachwycił się nią po ujrzeniu obrazu Umierająca święta Magdalena pędzla Simona Voueta. Pisał o nim tak:

Jest tam para uskrzydlonych aniołów, które sfruwają ze swych siedzib pełnych niebiańskiej radości, by przyjąć do siebie duszę. A ona klęczy naznaczona bladością śmierci, umierające zaś ciało osuwa się w ramiona aniołów. Jakże delikatnie jej dotykają! Tylko koniuszkami swych różanych palców unoszą ukochaną istotę, która teraz umknęła spod ręki losu. A ona rzuca na nich spojrzenie umierających oczu, jakby już oglądała nieskończoną szczęśliwość niebiańskich błoni. Jeszczem nigdy nie widział czegoś tak wzruszającego i podniosłego ${ }^{30}$.

Jak bardzo obraz ten wpłynął na jego wyobrażenie śmierci, widać w ostatnich listach, gdzie opisuje niebo, dla którego porzuca ziemię. Różnica jest taka, że poeta nie znalazł w swojej wizji miejsca dla boskich pośredników ani samego Boga. Dusze uwolnione z ciała same przeobrażają się w piękne anioły, zażywające wiecznej szczęśliwości. Uzyskana w samobójstwie tożsamość - jak pisze Maria Janion - daje nieśmiertelność poprzez śmierć jako absolut, transcendencję w świat ponadzmysłowy i ponadnaturalny, nie rozumiany jednak w sposób religijny ${ }^{31}$. W listach przed samym samobójstwem Kleist wyznawał, że jemu i Henriettcie marzą się „prawdziwe niebiańskie łąki i słońca, w których blasku będą wędrować z długimi skrzydłami u ramion"32. Jego wizje są zwiewne, eteryczne, pełne łagodnych i pastelowych kolorów. Gaston Bachelard podkreślał, że właśnie wyobraźnia związana z powietrzem, w przeciwieństwie do wodnej czy ognistej, tworzy szczęśliwe obrazy radości i wzniosłości. Lot symbolizuje pragnienie czystości oraz siły uduchawiającej. Kleist przyrównywał również swoją duszę oderwaną od ciała do „radosnego statku powietrznego” unoszącego się nad światem. Nic dziwnego, że metaforyka ta przywołuje w listach poety motyw „wielkiej podróży”, która ma być nowym etapem życia po samobójstwie. Rzeczywiście, Heinrich i Henrietta skrupulatnie przygotowywali się do śmierci jak do podróży wyczekiwanej z wielką niecierpliwością. Tym bardziej, że z biegiem czasu zniechęcenie do świata i przygnębienie pisarza przybierały na sile. Miesiąc przed śmiercią zwierzał

\footnotetext{
28 Tamże, s. 421.

${ }^{29}$ Tamże, s. 430.

30 Tamże, s. 443.

${ }^{31}$ H. Kleist, Dramaty wybrane, s. 353.

${ }^{32}$ Tenże, Listy, s. 510.
} 
się kuzynce: „Ciężko mi na duszy i mroczno, znikąd najmniejszego promyka światła na przyszłość, jakiej mógłbym wyglądać z choćby odrobiną radości i nadziei” ${ }^{33}$. Poeta stracił wiarę w powodzenie swojej misji, utwierdził się w przekonaniu, że nad wszystkimi jego poczynaniami ciąży fatum. Zrezygnowany wyznawał: „Wszystko, czego bym się tknął, idzie na marne, jak zawsze, ilekroć się już zdecyduję uczynić jakiśs stanowczy krok, ziemia usuwa mi się spod nóg" ${ }^{34}$.

Na następne trzy tygodnie korespondencja Kleista urywa się. Tyle czasu potrzebował, aby w pełni dojrzeć do śmierci i odnaleźć towarzyszkę swojej ostatniej podróży. 9 listopada przesłał kuzynce Marii von Kleist pierwszy z trzech pożegnalnych listów. Nie ma w nim rozpaczy i cierpienia, ale radość z powodu przezwyciężenia wszelkich ziemskich więzów, „triumfalna pieśn duszy”, która w końcu opuści ciało i znienawidzony świat. Autor Markizy O. nie widział tu dla siebie żadnej przyszłości, podkreślając: „umieram, bo mi na tej ziemi nie pozostaje nic, czego bym się mógł jeszcze nauczyć i co mógłbym zdobyć” 35 . Nie do zniesienia była dla niego również teraźniejszość, pisał: „moja dusza jest tak zraniona, że nawet [...] światło dnia sprawia mi ból swoim blaskiem"36. Także spotkanie z rodziną przyczyniło się do ostatecznej decyzji Kleista o samobójstwie, gdyż podczas wspólnego obiadu został przez nią potraktowany jako „całkowicie bezużyteczny” człowiek, skazany na klęskę i niegodny uwagi. Pisarz, który tyle wysiłku poświęcił dla ratowania własnego wizerunku publicznego i zdobycia sławy, nie mógł znieść lekceważenia otoczenia. Dlatego spotkanie Adolfiny Henrietty Vogel, nie tylko rozumiejącej wstręt do życia poety, ale podzielającej też pragnienie śmierci, napawało go ekstatyczną radością. Kleist uważał wspólne samobójstwo za „najwspanialszą, najrozkoszniejszą spośród wszystkich śmierci”. Co więcej, w swoim urojonym świecie pojmował ją jako dar od Boga, nagrodę za największe cierpienia życia. Każdego dnia padał na kolana i w modlitwie dziękował za tę łaskę. Podwójne samobójstwo zaplanował z wielką świadomością estetyczną. Przeszło ono do historii jako akt filozoficzno-literacki i przyniosło mu większą sławę niż jego twórczość.

Szokujące jest to, że Heinrich i Henrietta wysłali listy do swoich przyjaciól, pisane już z perspektywy umarłych, prosząc o zajęcie się ich doczesnymi szczątkami. Pisma te były nie tylko swego rodzaju testamentem, instruującym, co zrobić z ich majątkiem, ale też świadectwem szalonej radości i upojenia śmiercią. Zgon paradoksalnie jawił im się jako absolut, najwyższy cel oraz jedyna możliwość osiągnięcia pełni życia. Listy Kleista, podobnie jak Hymny do nocy Novalisa, wyróżnia Lust im Tode, czyli rozkosz w śmierci. Rzeczywiście, kiedy przyjechali do gospody pod Nowym Dzbanem, w pobliżu której mieli się zabić, cały czas żartowali, byli w doskonałych humorach. Nie było w nich widać żadnego wahania, smutku czy przygnębienia. Pozwolili sobie nawet na dozę czarnego humoru: w rozmowie z gospodarzem poeta zaznaczał, że

\footnotetext{
33 Tamże, s. 502.

${ }^{34}$ Tamże, s. 503.

35 Tamże, s. 507.

${ }^{36}$ Tamże, s. 508.
} 
choć nic nie zjedzą na obiad, potem wynagrodzą to sobie w „dwójnasób”, a kolejnego dnia wieczorem: „już sobie solidnie podjedzą" ${ }^{37}$. Kochankowie wiedzieli, że w pierwszym przypadku będą już martwi, a w drugim najprawdopodobniej spoczną w grobie. Uprzedzili gospodarzy, że wieczorem przyjadą goście, do których wysłali w południe listy, zamówili też dla nich sutą wieczerzę i nocleg. Ich plan był dopracowany w najdrobniejszych szczegółach. Kiedy odprawili kuriera z pożegnalnymi listami do Berlina, kilka razy pytali, o której godzinie może dotrzeć na miejsce, ponieważ chcieli się zabić w odpowiednim momencie. Gdy zbliżała się godzina doręczenia ich pism, udali się na przeciwległą stronę jeziora tłumacząc, że ze względu na wyjątkowo piękny widok właśnie tam pragnęliby wypić kawę. Chcąc, aby szybko odnaleziono ich ciała, rozkazali po wypiciu kawy przynieść służącej wymyte filiżanki z powrotem. Kleist najpierw strzelił Henriettcie w serce i zanim pokojówka uszła 30 kroków, gorącą jeszcze lufę przystawił do ust i odebrał sobie życie. Radość nie opuściła ich do samego końca. Nawet ludzie, którzy potem znaleźli zwłoki Heinricha i Henrietty, wspominali, że: „ich twarze nie były zmienione, oboje wydawali się spokojni i pogodni”. Ostatnie chwile kochanków przypominają los bohaterów noweli Kleista Narzeczeni z San Domingo, którzy podobnie umarli i po śmierci również zostali pochowani w jednym grobie, niedaleko miejsca zgonu.

Nigdy nie dowiemy się na pewno, czy poeta wierzył rzeczywiście w ideę, dla której poświęcił życie swoje i Henrietty, czy była to jedynie świadoma kreacja, mająca mu zapewnić sławę większą niż za życia. Za tym ostatnim może przemawiać fakt drobiazgowo zaplanowanego samobójstwa, zadziwiająca dbałość o szczegóły, rozesłanie listów i zaaranżowanie wszystkiego tak, aby nikt nie mógł im przeszkodzić. Z drugiej strony zachwyt i pożądanie śmierci wydaje się autentycznym uczuciem poety, co znajduje wyraz również w jego twórczości. Już Maria Janion podkreślała, że bohaterowie utworów Kleista dojrzewają do śmierci. Twórczość pisarza, burzliwa jak czasy, w jakich przyszło mu żyć, ściśle wiąże się z jego listami przepełnionymi fascynacją umieraniem. Możliwe, że to właśnie ją miał na myśli zwolennik klasycystycznej harmonii Johann Wolfgang Goethe, gdy krytykował poetę: „We mnie zawsze, mimo iż jak najszczerzej mu współczułem, budził ten poeta zgrozę i odrazę, jak przez Naturę pięknie zaplanowane ciało, którym owładnęła nieuleczalna choroba" ${ }^{38}$. Nastrój tragizmu, grozy, terroru, niesprawiedliwości społecznej i triumfu zła dominuje głównie w nowelach Kleista. Wyłania się z nich brutalny świat, który nawet pod przykrywką religii, w majestacie Kościoła, dopuszcza się okrutnych zbrodni. Doprowadza do nich fanatyzm, czyniący z ludzi bestie, kierujące się tylko żądzą krwi. Poeta obnaża bieguny ludzkiej natury, potrafiącej w obliczu tragedii zjednoczyć się z innymi bez względu na status społeczny, ale też bardziej niszczycielskiej niż siła żywiołów, tak jak w Trzęsieniu ziemi w Chile. Postacie utworów Kleista przypominają bohaterów bajronicznych, którzy w momencie pokonania wszystkich przeszkód i dotarcia do celu nagle tracą go bezpowrotnie. W przeciwieństwie do nich, gorąco się modlą i czekają na interwencję

\footnotetext{
${ }^{37}$ Tamże, s. 520.

38 Tamże, s. 38.
} 
Opatrzności, podczas gdy niebo pozostaje zimne i puste. Tak dzieje się w Trzęsieniu...: „Don Fernando, widząc swego małego Juana z wypływającym mózgiem z czaszki, podniósł oczy w niewysłowionym bólu ku niebu"39. Bohaterowie utworów Kleista również często poświęcają swoje życie, aby ratować ukochaną osobę: czyni tak Józefina we wspomnianym opowiadaniu, Toni w Narzeczonych z San Domingo, a także Lisbet, aby pomóc mężowi, tytułowemu Michałowi Kolhaasowi. Te wszystkie kobiety stanowią wzór godny naśladowania, każda z nich umiera w męczarniach. Śmierć jawi się też jako pragnienie połączenia się ze zmarłym ukochanym i niemożność życia bez niego. Tak postępuje Gustaw, który w wyniku fatalnej pomyłki, tragicznego zaślepienia, zabił Toni, choć ta, aby go ratować, wyrzekła się rodziny i wpajanych jej wartości. Kiedy chłopak zrozumiał swój błąd, zastrzelił się nad ciałem narzeczonej, którą wcześniej oskarżył o zdradę. Również nowela o Michale Kolhaasie nie jest tylko dramatem starań przywrócenia ładu społecznego, ale rozpaczliwym dążeniem do śmierci po utracie sensu życia. Badacze zgodnie podkreślają, że pod wpływem lektury Kanta Kleist stał się wyznawcą instynktu, dlatego też w dziełach poety często spotykamy studium ludzkich namiętności. Mistrzowsko dokonał tego w Pentesilei, tragedii o królowej Amazonek, która w przypływie obłędu rozdziera ze sforą swoich psów ukochanego Achillesa. Fascynacja mitem o Akteonie, Orfeuszu i Heraklesie daje obraz jednego z najbardziej krwawych dramatów w literaturze niemieckiej. Samo morderstwo jest przedstawione niezwykle realistycznie, a zwłoki, przypominające bezkształtne mięso, tak makabryczne, że:

\section{wieczna Miłość \\ niby ladacznica \\ w śmierci niewierna, \\ odwraca swe lica ${ }^{40}$.}

Następuje tutaj perwersyjna zamiana metafory „pożreć z miłości” w znaczenie dosłowne. Kiedy Pentesilei wraca świadomość i pojmuje ze zgrozą swój czyn, postanawia podążyć za ukochanym. Sposób, w jaki umiera, jest niezwykły, ponieważ rozbrojona przez wojsko, zabija się siłą woli. Natomiast Książę Homburgu stanowi zapis zmagania się z niesprawiedliwym wyrokiem śmierci: od rozpaczliwych prób ratowania życia za wszelką cenę, przerażenia śmiercią, po pokorne uznanie jej za słuszną karę, aż do jej pragnienia.

Nie można oprzeć się wrażeniu, że takiego bakcyla śmierci poeta zaszczepił również Henriecie. Był winny nie tylko jej morderstwa w sensie fizycznym, ale także w wymiarze moralnym. Zaraził kobietę ideą urojonego świata, wizją wiecznej szczęśliwości poniekąd z pobudek czysto egoistycznych. Przede wszystkim nie chciał umierać sam, a po drugie, nie zależało mu w istocie na dobru pani Vogel, której sytuacja życiowa przedstawiała się daleko lepiej niż Kleista. Miała ona kochającego męża, piękne dziec-

${ }^{39}$ H. Kleist, Dramaty i nowele, oprac. M. Urbanowicz, Wrocław 1969, s. 475.

${ }^{40}$ Tamże, s. 170. 
ko i oddanego ojca, którzy zrobiliby dla niej wszystko. Poeta odczuwał wręcz perwersyjną radość ze świadomości, że Henrietta chce to wszystko porzucić dla niego. Miłość pojmował nie jako wspólne życie, ale wspólny zgon. Pisał, że grób ukochanej jest mu „milszy niżeli łoża wszystkich cesarzowych świata” ${ }^{41}$. Upatrywał istotę prawdziwego związku w oddaniu się w ofierze temu, kogo się miłuje, a także gotowości pójścia za nim choćby do piekła.

Problematyczną kwestią pozostaje to, czy Kleist rzeczywiście kochał Henriettę. W listach do Marii kilkakrotnie zaznaczał, że nie mógłby z tą kobietą spędzić życia, a jedyną rzeczą, która ich łączy, jest decyzja wspólnego zgonu. Poeta raczej pokochał ideał pani Vogel niż ją samą. Świadczy o tym również list do niej, skreślony przez Kleista niedługo przed śmiercią. Stanowi on dowód całkowitego rozstroju nerwowego. Pisarz dokonuje w nim enumeracji określeń ukochanej, gdzie patos i sentymentalne deminutywy dają iście groteskowy efekt. Słowa wyryte na grobie Heinricha: „Teraz, o nieśmiertelności, jesteś cała moja”“2 brzmią jak zwrot do ukochanej kobiety, którą w końcu się zdobyło, i nasuwają przypuszczenie, że to właśnie śmierć była w istocie prawdziwą miłością Kleista, a nie Henrietta.

Ewa Modzelewska

\section{Obsession with Death in the Works of August Antoni Jakubowski and Heinrich von Kieist}

\section{Summary}

The aim of this paper is to show the work of two romantic authors, namely Heinrich von Kleist and August Antoni Jakubowski. They were not only fascinated by death, but they also died at a young age. By analyzing their biographies, poetry and letters I will present utterly different perceptions of death. Kleist, for instance, longed for it like the sick long for a cure. He perceived death as the beginning of a big adventure, in which he was to be accompanied by Henrietta. They found common ground thanks to a paradoxical decision of dying, not living, together. In addition, I will also discuss the less known work of Jakubowski, the illegitimate son of Antoni Malczewski. He committed suicide at the age of 21, while being on exile in America, right after the November Uprising. Furthermore, I will touch upon his autobiographical poems, in which one can notice his maturation towards death as liberation from a foreign world, without hope of coming back to his homeland. This poetry is a testimony of growing depression and misery, while the motif of death becomes the author's obsession.

\footnotetext{
${ }^{41}$ H. Kleist, Listy, s. 510.

${ }^{42}$ Tenże, Dramaty wybrane, s. 337.
} 